\title{
'With certain grand Cottleisms': Joseph Cottle, Robert Southey and the 1803 Works of Thomas Chatterton
}

On 12 January 1803, Robert Southey wrote to John Rickman with the news that he had finally published his edition of the complete Works of Thomas Chatterton. Now completed, the book proved to be much to the satisfaction of Southey's co-editor Joseph Cottle: 'Chatterton is finished - with certain grand Cottleisms wherewith I shall make mirth for you when we meet'. ${ }^{1}$ These 'grand Cottleisms' were not just uttered extempore: certain of them have survived in letters, and they reveal not only the impulses behind the edition and the ambitions of the two editors, but also suggest why this edition mattered so much, and why it was destined to be a significant document in making the Romantic myth of Chatterton. At the time, the project confirmed Bristol's position at the centre of what would later be known as the Romantic movement-Chatterton was considered to be a Bristolian, as were Southey and Cottle, and completing the project had involved various members of the regional intelligentsia. The story of its inception, compilation, and publication presents, then, an alternative to narratives of the period that are focussed upon the poetic collaborations of William Wordsworth and Samuel Taylor Coleridge.

Cottle is indeed best known as the publisher of Wordsworth and Coleridge's Lyrical Ballads
(1798), but he had effectively retired from bookselling by the time the Works of Chatterton appeared. ${ }^{2}$ It was in fact the commercial failure of Lyrical Ballads - to which the public were slow to respond - that had hastened the collapse of Cottle's publishing activities, with the result that he was gradually selling his copyrights to T. N. Longman. The Works of Chatterton was underwritten by Longman and produced as an act of charity for Chatterton's surviving family - his sister, Mary Newton, and her daughter, also called Mary - and it had, somewhat ironically, a far greater immediate impact than Lyrical Ballads. This was due in part to the considerable impetus the edition received from a public row between Southey and Herbert Croft, author of Love and Madness (1780) waged in the pages of the Monthly Magazine and the Gentleman's Magazine (1799-1800). ${ }^{3}$ But the Southey-Cottle Works was also the earliest attempt to produce a comprehensive account of the Chatterton phenomenon that had been haunting the literary world for a quarter of a century. The edition presented an opportunity to investigate Chatterton's precocious - if fatal-genius, and to examine the staggering range of his literary production. Chatterton appealed because he was young, passionate, wayward, and radical. His writings were 
similarly wild, ranging from intricate medieval forgeries (the Rowley works) to vituperative political satires - but how could the dreamy imaginative richness of the Rowley world coexist with his extreme radicalism? Southey, the onetime Pantisocrat, was initially drawn to Chatterton's strange brew of medievalism and political savvy, but it was Cottle's tampering emphasizing certain aspects of Chatterton's œuvre against others (the Rowley forgeries against the political satires), that would help to mould the poet into an archetypal figure for a new generation of writers. This edition was then the canonical Chatterton for the Romantic period (Wordsworth and Coleridge were both subscribers to the edition), and was of enormous influence in presenting for the first time the dizzying extent of Chatterton's literary achievements - and it is revealing to discern the hand of Cottle in Southey's high-minded project.

According to Donald Taylor, the 1803 Southey-Cottle Works is of little interest textually, 'derived primarily from previous editions, earlier printings, holographs still extant, and non-authoritative transcripts', and it also tends to be inaccurate. ${ }^{4}$ But it was the first and until Taylor himself in 1971, the only attempt at a collected edition covering all of Chatterton's verse and prose. Southey and Cottle published 32 authentic pieces for the first time, and brought 45 previously printed pieces into the canon; they also reproduced nine pieces of doubtful authenticity (seven of which were from the 'Hunter of Oddities' series) and erroneously printed two texts not by Chatterton. Including correspondence and memoirs, a total of 112 pieces were collected or printed for the first time.

The three volumes of the Southey-Cottle Works begin with George Gregory's Life (1789) and a reprint of Chatterton's Miscellanies in Prose and Verse (1778), volume two is drawn from Jeremiah Milles's edition of the Rowley poems (1782), and volume three is predominantly unpublished or uncollected pieces (including those texts used for William Barrett's History and Antiquities of the City of Bristol, 1789); much use is also made of Robert Glynn's bequest to the British Library. ${ }^{5}$ The edition concludes with extracts from Edward Gardner's Miscellanies (1798), various letters including one from Mary Newton on her brother admitting to writing various Rowley poems, and a bibliography of the Rowley Controversy compiled by Joseph Haslewood. ${ }^{6}$ Annotation is very sparse, except in the Rowley volume, and although Southey-Cottle is in no sense a variorum the footnotes here are collected from Tyrwhitt, Milles, Bryant, and Barrett, and from notices in newspapers and magazines. ${ }^{7}$ The edition is very fastidiously printed, particularly in this Rowley volume: for example, a page of 'Eclogue the Second' has five strata of type-four lines of text, Chatterton's footnotes, Tyrwhitt's footnote, a note continued from the previous page, and a further footnote to that note. ${ }^{8}$

Ostensibly, Southey arranged the texts and Cottle wrote a handful of explanatory essays, but Cottle also seems to have done a considerable amount of editing - not to mention bowdlerizing-himself; indeed, Cottle was much more involved in publishing Chatterton than he had been in the production of Lyrical Ballads, to the extent that his values are perhaps stamped on the edition far more deeply than those of his co-editor. This is how the more conservative version of Chatterton as an ineffable genius, barely of this world, became delineated. In this, Cottle was assisted by help received from such characters as George Catcott (associate-one might say dupe - of the poet, and by then a professional Chattertonian), Thomas Eagles (who had financed The Execution of Sir Charles Bawdin, 1772), and Edward Williams (a.k.a. the Welsh antiquarian and forger, Iolo Morganwg, who had transcribed Chatterton's father's catch for three voices from the 
European Magazine, 1792, reprinted in the edition). ${ }^{9}$

Never one to resist interfering, the Pumblechookian Catcott had already taken it on himself to visit Chatterton's sister Mrs Newton with a progress report:

I have the pleasure of informing you, that 「the Plan $\rceil$ meets entirely her approbation; $\lceil$ and $\rceil$ that she expresses the most lively Gratitude for the trouble you \& your Friend have taken in behalf of herself and Daughter. $^{10}$

Mary Newton herself wrote to Cottle a week later (25 March 1802):

$\mathrm{M}^{\mathrm{r}}$ Catcott call ${ }^{\mathrm{d}}$ on me with the pleasing news that $\mathrm{M}^{\mathrm{r}}$. Southey \&c had determind upon a plan of Publishing my Brothers works. You had purposed the present plan to me before you left Bristol and I coincided with it, and I do assure you Sir, it have my full approbation. ${ }^{11}$

It almost sounds as if this has been dictated by Catcott, but the most telling feature of this letter is that she asks for an advance of a 'few pounds'. She was ailing and impoverished; Longman and Rees forwarded $£ 30$.

The main collaborator on the project was Joseph Haslewood-antiquarian, editor, and subsequent founder of the Roxburghe Club. ${ }^{12}$ Haslewood's collection of Chattertoniana was, as Southey noted to John Britton, later renowned as an antiquarian topographer, 'extraordinary' ${ }^{13}$ He had not only compiled a comprehensive library of books and pamphlets, but had also collected clippings of Chatterton's contributions to the Middlesex Journal (1769-70), Town and Country Magazine (1769), and Lady's Magazine (the latter proving that Chatterton did not write under the name 'Asaphides'). In other words, Haslewood supplied many details of Chatterton's uncollected verse, indicating that 'Clifton', for instance, was first published in the European Magazine for January 1792 (interestingly, the copytext ultimately used by Cottle was from Glynn's collection). Haslewood also had cuttings from the Gentleman's Magazine, Monthly Review, Critical Review, European Magazine, Morning Post, St. James's Chronicle, Public Advertiser, and many other ephemeral publications, detailing the ebb and flow of the Controversy from 1778 to the present, and these arguments gathered against the authenticity of Rowley proved indispensable for Cottle when he came to write his critical essays. ${ }^{14}$

It was probably the poet, literary journeyman, and eccentric, nankeen-pantalooned George Dyer who first made contact with Haslewood, acting as an emissary for the Bristol editors. ${ }^{15}$ Southey had asked Dyer to try and authenticate Chatterton's burletta The Revenge (first published in 1795), and following the advice of a bookseller, Dyer's trail led to Haslewood. Southey immediately paid him a visit, and Haslewood wrote to Dyer on 18 June 1802:

\section{Sir/}

The MS Copy of the Revenge was purchased by $\mathrm{M}^{\mathrm{r}}$ King of the late $\mathrm{M}^{\mathrm{r}}$ Luffman Atterbury of Abingdon Westminster for 5 Guineas it was afterwards given to the late John Egerton in order to be published and from the information of $\mathrm{M}^{\mathrm{r}} \mathrm{K}$ I understand the MS. was lost, or supposed to be lost at the Printing House $[.]^{16}$

This note became literally the last word in the Southey and Cottle Works, when it was reproduced in Haslewood's bibliography, a work that Southey had promptly commissioned for the edition:

When $\mathrm{M}^{\mathrm{r}}$. Southey did me the favour of a call on the subject of Chatterton I gave him a short list of the Pamphlets pro \& con since then I have perused every writer on the 
subject and had made a complete Copy of every Title page in the order they have been published intending to add some observations on each and transmit them to $\mathrm{M}^{\mathrm{r}}$. Southey presuming as he adopted Gregory's Life such list might be of use to him; but as you mention the work as nearly closed presume my delay in that respect renders the communication unnecessary. -

Dyer leapt into action, insisting 'There is yet time for you to send the parcel. It should be made into a parcel, and directed R. Southey, Bristol.' Dyer also made plans to visit Haslewood, although in the event was entirely preoccupied with 'dictioneering matters' and quite typically forgot.

Meanwhile, Haslewood sent his list of books and pamphlets on $2 \mathrm{July}$, insisting that especial care be taken over transcribing the title-pages; he had also made 'observations' on each entry, and was in a mood to go after 'your antagonist' Herbert Croft. Haslewood evidently also sent a parcel of books, which Dyer and Cottle had already gleefully perused, as Dyer indicated with a gloating gratitude: 'I have sent your parcel to Southey, who I doubt not has acknowledged the receipt of it. I thank you for much pleasure rec ${ }^{d}$. from it myself: for as Cottle thought himself authorized to open it, I pleaded privilege with my conscience. $\lceil \&$ read it $\rceil$ '.

Southey was duly impressed by Haslewood's scholarship, and wrote a gracious letter on 12 July 1802.

Sir,

I feel myself greatly obliged for the list of publications wherewith you have forwarded me, \& think it should be printed at full length with the observations as you have written it. Collectors will value the minuteness \& those who are not Collectors will have a compleat view of the controversy.

The pieces signed Asaphides ${ }^{17}$ in the Miscellanies have already been printed. it would perhaps then be proper to print all the others that have that signature at the end of Chattertons known poems. Whoever the writer was he certainly imitated Chatterton. there are some "Saxon poems" like Ethelgar \& Gorthmond in the Ladys Magazine. ${ }^{18}$

Those parallel passages which appeared worth reprinting I have placed as notes to the passage in the text. I am now sorry that this method was adopted before I could profit by those which you have collected.

For the assistance Sir which you have given \& for what you may yet give, I shall make public acknowledgement $-\&$ feel private obligation. I am Sir with respect your obliged humble servant

Robert Southey

Kingsdown. Bristol.

July 12. 1802

Shortly after this (8 August), Dyer was reassuring Haslewood 'that $\mathrm{y}^{\mathrm{e}}$ papers will be printed, that $\mathrm{y}^{\mathrm{e}}$ work will be out in about a month or 6 weeks'. It actually took four times as long. But although the torrent of Haslewood's erudition continued unabated, the vast majority of his bibliographical references were never incorporated into the edition-indicative of the intentions of Southey and Cottle to make their Chatterton an accessible poet rather than the preserve of antiquarian bibliography.

On Saturday 26 November, Cottle returned Haslewood's books, and urged him to 'let us have the List of Books on Monday, as that is the only article now for which we wait' - although in fact the engraved illustrative plates also remained to be finished. When the list of publications appeared, however, Cottle decided to cut Haslewood's longest observations, explaining on 29 November, 'We by no means wish an Epitomy of Works, but the mere titles, with a few simple remarks if there was any thing which particularly required them'. But Cottle was also concerned about 
Haslewood's remarks concerning Herbert Croft, and his first objection was to the whole relating to Love and Madness. It will be construed into an attack upon < living $>$ Sir $\mathrm{H}$ Croft, and as neither $\mathrm{M}^{\mathrm{r}}$ Southey or myself have said any thing concerning him, we should not chuse for a $3^{\mathrm{d}}$ Person.' Significantly, Croft is not explicitly criticized in the edition, despite Love and Madness being given as the source for early material such as 'Apostate Will'.

Certainly neither Southey nor Cottle had anything to fear from him: they had already laid before the public the 'black scene' of Croft's duplicity in obtaining papers from Chatterton's mother and sister, Southey had defeated Croft in the magazines, and they had assembled their subscribers, as I have argued elsewhere. ${ }^{19}$ But it is remarkable that Croft is treated so lightly. $\mathrm{He}$ was very much the villain of the piece and in effect the entire reason that Southey and Cottle embarked on the edition. This reluctance to attack Croft suggests the growing conservatism of a project, if it also suggests a certain high-mindedness in refusing to allow petty criticism of Croft's heinous exploits to tarnish the poetic memorial.

Haslewood wrote back straightaway, somewhat flustered:

it is not worth mentioning my rule of adopting a Cause is to do my best to support it \& certainly thought myself doing it as $M^{r}$. Southey's expressed himself obliged by the List of Publicons and "that it should be printed at full length with the observons as I had $<$ wh $>$ written it Collectors would value the minuteness \& those that were not Collectors would have a complete view of the controversy." and where on second perusal I had any way enlarged it was only 「only with an intention to render it more worthy any work he put his name to as Editor.

Cottle had also reminded Haslewood of his own sometime plans to publish an account of
Chatterton, but Haslewood clearly felt that he had now discharged all of his knowledge on Chatterton: ' < Upon > the point of any publicon from me $\mathrm{w}^{\mathrm{d}}$. have been pieces by $\mathrm{C}$. omitted by his Editor as those

$<$ have been $>$ are communicated there is not $<$ any $>\lceil$ sufficient $\rceil$ reason for me to use pen $<$ further $>$ on $\mathrm{y}^{\mathrm{e}}$. subject ${ }^{-}$

Nonetheless, Haslewood dashed off a frantic letter two days later with a handful of corrections to his bibliography (which were more or less incorporated), before succumbing to a sore throat and cold. He wrote to Cottle from his sick bed on 10 December, hoping that the book was printed to help him through 'the lassitude of illness ... convinced I shall be much 「better $\rceil$ pleased with $\mathrm{Ch}^{\text {s }}$. notions "Than counting the clock for gargles \& potions"'. Cottle replied on 'Saturday Dec ${ }^{\mathrm{r}}$ something 1802' that although the Works would not be ready until the new year, nevertheless 'You may depend upon having one of the first copies that is delivered ${ }^{\prime 20}$

Much of Haslewood's collection of Chattertoniana related to the political satires, and so it is perhaps surprising that more use was not made of his sources. But this reluctance to engage fully with the worldly, Churchillian Chatterton plying his wares in the literary marketplace is symptomatic of the Southey-Cottle edition. Southey had initially been drawn to Chatterton's ability to switch rapidly between voices, styles, and registers, from imaginative introspection to radical politics; but whether to save Mrs Mary Newton's blushes, or out of his own sheer embarrassment or moral cowardice, Cottle left some pieces out of the edition, and bowdlerized others. For example, on 18 March 1802 the elderly and meddlesome Catcott had written to Cottle objecting to the inclusion of 'The Exhibition' in the forthcoming Works. ${ }^{21}$ This is a ripe example of Chatterton's 'political and obscene ribaldry', describing a clerical exhibitionist: 
What is that thing of Flatulence and Noise

Whose Surgery is but a Heap of Toys

That thing once Slave to me, who boasts he's got

A Treatise on the Matrix piping hot

Who can with Microscopic Glass descry

New hidden Beauties in the nether Eye

What if that Thing was suffer'd to escape

Because his Manhood could not reach a

Rape ... [and so on] (11.371-8) ${ }^{22}$

Catcott wrote thus:

Dear Sir,

I have consulted with some of my most confidential Friends, respecting the

Publication of the Exhibition and they are unanimously of Opinion, that it ought to be altogether suppressed. I confess to you that this coincides entirely with my own Ideas upon the subject, and I am persuaded that both $\mathrm{M}^{\mathrm{r}}$ Southey \& yourself, would see the impropri「e $\rceil$ ty of laying it before the World.

Catcott admitted to be 'almost ashamed to be in possession of such an abusive Libel' and warned that 'The insertion of any part of it would not only be a stigma to the Volume, but would raise a Cloud of Enemies against the Undertaking'.$^{23}$

'The Exhibition' was expelled from the edition. Even Southey was surprised and slightly dismayed -if philosophical - by some of the transcription he found himself engaged upon. He wrote to Charles Danvers on 23 March 1802:

I have a heavy job upon my hands. To day the Museum doors were opened to me and alack and a-well-a-day I find not less than 1500 unpublished lines of Chatterton to transcribe from manuscripts not always the most legible. However this will give the book a value, tho between you and I, neither you or I are likely to be delighted with poetry upon temporary or local subjects - wit and genius wasted. ${ }^{24}$
Indeed, later, in Malvern Hills (1829), Cottle insisted that Chatterton's reputation 'rests, exclusively, on Rowley, the deliberate effusion of his genius. None of his other writings, it must be admitted, possess the principles of vitality.$^{25} \mathrm{He}$ goes on to say that the Works is marred by accepting all of the pieces in Miscellanies as genuine. He was now satisfied that 'Memoirs of a Sad Dog' and several other pieces had been wrongly attributed to Chatterton-although Cottle is the only editor seriously to have doubted 'Sad Dog' and the nature of his objection is completely unknown. ${ }^{26}$

Cottle fiddled with other texts. Among Haslewood's collection was a graingerized copy of Milles's 1782 edition that included a manuscript of 'Kew Gardens' in Isaac Reed's hand - the source of printed extracts of the poem from perhaps as early as $1778 .{ }^{27}$ Cottle must have examined this version - which was almost eleven hundred lines long-and yet he published a version a tenth of the size, taken from a manuscript possibly made by Michael Lort, in the hands of one Dr Halifax. 'Kew Gardens' was not published in full until Taylor's edition of 1971.

Likewise, Cottle specifically requested from Haslewood the text of 'Resignation' printed in the Freeholder's Magazine (1770), 'to compare a couple of doubtful Words', although in the event the poem as printed not only contained various lacunae, but was also bowdlerized of several couplets. The poem attacks the Prime Minister Bute for his supposed affair with Augusta of Saxe-Gotha, the Princess Dowager of Wales ('the Carlton Sybil'):

Nor yet be unthankful he for power and Place He prais'd the Sybil with distinguished Grace And oft repairing to her Cell of Hate He laid aside the Dignity of State Fierce suck'd her secret teat: the wither'd hag Repaid his Ardor with a wealthy bag; Oft when replenished with superior might 
The Thane has sucked three Million in a Night Or when the Treasury was sunk with spoil Three Coronets have recompensed his Toil And had not virtuous Chudleigh held the Door She to this moment might have been a Whore. (ll. 255-66) ${ }^{28}$

Cottle silently omitted this section, presumably for reasons of decorum. While he was happy to reprint bawdy innuendo in 'The Whore of Babylon' (for example, ll. 101-2, and 420), the queasy reference to the witches' mark (or supernumerary nipple) here was certainly not to his taste. ${ }^{29}$

But the main thrust of the Works was not simply to celebrate Chatterton's diversity, but to establish that he was the sole author of the Rowley works, and it was upon those pieces, rather than ephemeral political doggerel, that his reputation should stand. Cottle had a little coup here: another contribution from Mary Newton. She had written to Cottle again on 17 October 1802 with the following information:

You desire me to inform you all I know concerning Rowleys Poems, the whole of my knowledge amounts to no more than this. My Brother read to me the Poem on our Ladies Church. after He had read it several times, I insisted upon it $\mathrm{He}$ had made it. He

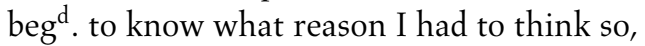
I added, His stile was easyly discovered in that poem[.] He replyd, I confess I made this, but dont you say any thing about it. When he read the Death of Sir Charles Bawden to my Mother she admire ${ }^{d}$ it and asked him if He made it. He 「reply $\left.{ }^{\mathrm{d}}\right\rceil$ I found the argument and I versified it. I never saw any parchment in my Brothers posession but the account of Cannings Feast with several scraps

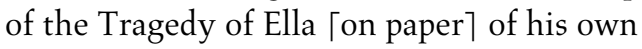
writing, that He read to his family, as a specimen of the treasure He had discovered in the parchment and He always spoke of the poems to his friends as treasure He had discovered in the parchments. ${ }^{30}$ [Transcript taken from the original manuscript rather than from the printed text.]

A minor textual cruce (probably Chatterton's deliberate error) was declared 'the strongest argument that has been adduced for the authenticity of the poems', and Southey and Cottle even reprinted such things as Chatterton's notes on medieval writers. ${ }^{31}$ The main burden of proof, however, was carried by Cottle's essays - notably his research into Chatterton's 'Account of the Family of the De Berghams'. ${ }^{32}$

Cottle believed that this fake pedigree was the key to Chatterton's ceuvre and could 'throw very important light on ROWLEY's POEMS, if not to decide the Controversy'.$^{33}$ Cottle proceeds by examining Chatterton's sources, and discovering that while he had indeed used genuine sources, there was no evidence there of the quotations he had used, and moreover, he had interpolated extra material into the pedigree. Cottle then declares the oral tradition 'a new and inadmissable species of evidence', and discovers some sources to be non-existent. ${ }^{34}$ The heraldic designs lack consistency and historical conformity, and contain errors; although 'It appears very evident that Chatterton had paid particular attention to the subject of Heraldry' ${ }^{35}$ Cottle finds only one indisputable fact, derived from John Weever's Antient Funeral Monuments (1767, first published 1631), and then points out that Chatterton uses this work elsewhere. He concludes that this document,

will exhibit Chatterton, to the advocates of Rowley, in a new light, it will demonstrate him to have indulged a peculiar taste for subjects connected with antiquities; it will prove him to have possessed a sound judgment in selecting names and incidents, adapted to his purpose; and will exhibit a mind capable forming a great and intricate 
plan, on the most slender materials, supported alone by nice arrangement and specious falsehood. ${ }^{36}$

Henceforth, however, Chatterton's pure genius is confirmed. It is a characteristic Cottle move, a Cottleism: Chatterton's forgery is transcended by his genius. Cottle's reasoning is that

In identifying the Priest of the 15th Century with the Bard of the 18th, as far as intellect extends, Chatterton must ever be considered as an almost miraculous Being, on whom was showered "The Pomp and Prodigality of Heaven!" ... All difficulties vanished before him, and every branch of knowledge became familiar to which he momentarily directed his luminous attention. ${ }^{37}$

This, then, is the figure of Chatterton that emerges in the Southey-Cottle edition, as steered by Cottle: the identification of an eighteenth-century poet with a fifteenth-century priest is an awe-inspiring imaginative feat. Cottle briefly speculates what another seventeen years would have brought, before concluding that Chatterton is perhaps 'the greatest Genius that ever appeared in the "Tide of Times"'.38 A 'grand' Cottleism indeed. On 28 October 1800, Cottle had effectively set the seal on his analysis, branding De Bergham copy books as fakes by inviting the notorious Shakspeare forger William Henry Ireland to sign the actual manuscripts with forged signatures of the bard - an utterly imbecilic Cottleism. ${ }^{39}$

Cottle continued his delighted attack against the existence of Rowley in his essay, 'Observations on Chatterton's Arms' ${ }^{40}$ This is another heraldic analysis giving a potted career of Chatterton's impositions (making great and rather spurious use of his Ossianics), and argues convincingly for the similarities between Rowley himself and the dozen other writers in Chatterton's medieval corpus - thus proving a single-author coherency among the various works. Cottle also answers the argument that Chatterton interpolated genuine manuscripts in a similar fashion, declaring, 'Whoever examines the beautiful Tragedy of Ella, will find an accurate adjustment of plan, which precludes the possibility of its having been matured by different persons at the distance of centuries' ${ }^{41}$ In other words, Cottle was emphasizing the contiguous poetic subject.

Cottle concludes this essay by insisting again on the significance of the two pedigrees, De Bergham and De Chatterton: both

exhibit unquestionable proof of that radical tendency of mind which Chatterton felt for inventing Plausible Fictions (the grand key to his character!) and in support of which sentiment his whole life forms one mass of authority. These additional proofs of his creative faculty, connected with that body of diversified anti-rowleian evidence already before the public, can leave a doubt on few minds, but that Chatterton possessed that peculiar disposition, as well as those pre-eminent talents, the union of which was both necessary and equal to the great production of Rowley. ${ }^{42}$

Cottle's own emphases guide the reader here: Chatterton is both 'radical' and 'creative', a prototypical Romantic rebel. And yet Chatterton's actual political and satirical radicalism, involving precisely those 'temporary or local subjects' in which Southey found 'wit and genius wasted', is played down. Instead, radicalism is now - like creativity - a state of mind, which Cottle can justifiably valorize in Chatterton. Heraldry, interpreted by Cottle as a sign system 'inseparable from heroic action', is replaced by a heroizing code of genius. This underscores Cottle and Southey's ambitions to canonize Chatterton and celebrate Bristol, in which 'Chatterton's tracing of imagined, individual heraldic identities was 
inseparable from the making of a history for Bristol and the creation of a regional identity'. ${ }^{43}$ Finally, in his 'Account of Rowley's MSS', Cottle offers a bibliographical/forensic analysis of Robert Glynn's collection bequeathed to the British Library, in sometimes rather droll form: 'This [MS] consists of two or three scratches with a pen, which, with the help of a strong imagination, may be supposed to mean a cathedral' ${ }^{44}$ Cottle describes Chatterton's aging techniques - with a sooty candle, with glue or varnish - and in the version of this essay rewritten for Malvern Hills, Cottle goes on to dwell upon Horace Walpole's questionable conduct, before returning to his favourite theme: 'In the calmest estimation it did appear little less than impossible that an uneducated boy, of about fifteen, should have produced the matured excellencies of Rowley; but genius expatiates in an atmosphere of its own, and, occasionally confounds the rigid scrutinizer, by exhibiting effects beyond the range of his calculation; and this example of Chatterton absolutely furnishes a New Feature in the History of the Human Mind!' ${ }^{45}$ Another grand Cottleism: 'genius' becomes the key to all mythologies.

In Malvern Hills, Cottle returns to this otherworldly theme, using the letters he had printed at the end of the 1803 Works to present Chatterton as an almost spiritual being:

his conversation was ingenious, and often strikingly animated... one who well knew Chatterton, described him to the writer, as a boy who appeared "like a Spirit," and to be possessed of, almost, supernatural attributes. His eye was black and penetrating; his forehead broad, and his whole aspect, in moments of excitement, unapproachably commanding.... ${ }^{46}$

This paper was read in Bristol 'to a crowded audience' in December 1828, shortly before the publication of Cottle's collection. All agreed that it proved 'so conclusive of the controversy, as identifying Chatterton with Rowley'. ${ }^{47}$ And by the time Malvern Hills was published, Cottle's demolition of Rowley in favour of Chatterton was considered complete. None other than William Wordsworth congratulated Cottle on his acumen (in a letter that Cottle assiduously reproduced):

My dear Sir,

I received yesterday, through the hands of Mr. Southey, a very agreeable mark of your regard, in a present of two volumes of your miscellaneous works. I have read a good deal of your volumes with much pleasure, and, in particular, the 'Malvern Hills,' which I found greatly improved. I have also read the 'Monody on Henderson,' both favourites of mine. And I have renewed my acquaintance with your observations on Chatterton, which I always thought very highly of, as being conclusive on the subject of the forgery.

With many thanks, I remain,

My dear Mr. Cottle,

Your old and affectionate friend,

William Wordsworth Patterdale, August 2d, $1829^{48}$

Cottle's defining statement in Malvern Hills is to return Chatterton to the prototypical originality of the pre-Romantic poet: 'the very first of all premature geniuses' ${ }^{49} \mathrm{He}$ distinguishes him from the Admirable Crichton and other child prodigies, autistic geniuses, autodidacts, and impostors like George Psalmanazar: 'Chatterton's superiority arises from that which is far more unequivocal; from his writings; from his original effort! (50 $^{50}$

The Southey-Cottle edition was a success on a number of fronts: the war of the Rowley was finally over, and even the Scottish reviewers were impressed with the production - much to Southey's gratification: 'the Chatterton', he said, had 'been noticed very respectfully there' ${ }^{51}$ This was Walter Scott in the 
Edinburgh Review, whose sixteen-page essay had praised the edition for its breadth and clarity. Despite the inferiority of the satirical material, Scott argued the Southey and Cottle Works gave a fuller understanding of 'the strange ambiguity of Chatterton's character' ${ }^{.}{ }^{52}$ Scott also concurred with the editors that this was not economic forgery: 'Without

considering the forgery of Rowley's poems in so heinous a light as if they had been a bill or a bond, and pecuniary advantage the subject of the fraud,' he wrote, nevertheless 'we cannot regard the imposture as of an indifferent or harmless nature'. ${ }^{53}$ The Scott review confirms that Chatterton's Rowley vision was

fundamentally different from his satirical and miscellaneous writing, which helpfully makes him a stranger, more ambiguous and variegated writer - ultimately a genius. Scott also asserts at the end of his review the insistent moral of Chatterton's life and death: 'it is better to prefer obscurity, than to attain, by the crooked path of literary forgery, the ambiguous reputation of an ingenious forger ${ }^{\prime}{ }^{54}$

This troubling shift into ethical aesthetics or crimes of writing became more insistent as the nineteenth century progressed, and was generally yoked with attempts at character analysis, psychological profiling, and, as the madness thesis gained ground, with psychiatric diagnosis. Henry Crabb Robinson remained no great fan of Chatterton, despite Wordsworth's benign influence. On 16 January 1842, he complained:

I never could enjoy Chatterton - tant pis pour moi, I have no doubt - but so it is.... I defer to the highest authority, Wordsworth, that Chatterton would have probably proved one of the very greatest poets in our language. I must, therefore think he was not a monster of wickedness, but he had no other virtue than the domestic affections very strongly. He was ready to write for both political parties at once.... ${ }^{55}$
Indeed, when Crabb Robinson inquired a day later of Wordsworth of Chatterton's abilities, Wordsworth responded with a warm sense of his 'marvellous Boy's' achievement:

I asked Wordsworth this evening wherein Chatterton's excellence lay. He said his genius was universal; he excelled in every species of composition, so remarkable an instance of precocious talent being quite unexampled. His prose was excellent, and his powers of picturesque description and satire great.... ${ }^{56}$

Wordsworth's opinion is surprising because it demonstrates a clear acknowledgement of Chatterton's achievements as a prose writer and satirist, which is what Cottle in particular had drawn attention from. The question of the political Chatterton had, however, recently re-emerged in John Dix's semi-fraudulent Life (1837), which resurrected the teenage rebel who had originally enthused the young Coleridge and Southey. ${ }^{57}$

What was at stake for the editors of the 1803 edition, then, was this residual sense that Chatterton was a suicidal monster, a lying hound, and a political opportunist. The Romantic myth that Southey tried, half-consciously, to promote, was of a mad genius and a radical freethinker, whose work was imbricated by poverty and suicide..$^{58}$ This story took precedence, and has since survived for over two centuries. But this version of Chatterton nevertheless needed to come to terms with his political and libertine excesses: although Chatterton had indeed written the Rowley poems, his genius required he spoke with a single voice - and this, as Wordsworth recognized, had to include Chatterton's satirical voice as well. Yet the 1803 Southey-Cottle edition ultimately sidestepped this problem through Cottle's anxious concern for propriety. It was conservative in the failure of the editors to confront Croft again and press home 
Southey's attack; it was conservative in their inadequate annotation to the political and satirical works (which, as Southey admitted, made the poems appear merely opportunistic, or local - and that from a Bristolian himself!); and it was conservative in their unfortunate bowdlerization - in a word, in Cottle tempering the rebel Chatterton that had so viscerally appealed to Southey. Whether this conservatism was the result of a failure of nerve, or just a misguided attempt to make the Works palatable for Chatterton's sister Mary Newton and to curb the excessive libertinism of the myth, remains open to further debate. Mary Newton was ceertainly extremely sensitive about the ceaseless sexual gossip that tainted the memory of her brother - from his own adolescent boasting in Bristol to his death in the garret of a brothel - and this may have affected the integrity of the edition.

What then of Mrs Mary Newton? Cottle described the scene in a letter to Southey (24 February 1804). Despite being forwarded $£ 30$, Mary Newton was desperate for the money that Longman and Rees were laboriously collecting from the subscribers, and sent several people around to visit Cottle inquiring after it. Cottle's letter reveals that he was very hurt by the suspicions entertained by Mrs Newton and her friends: 'There is nothing so distressing to my mind, as a behaviour which implies a suspicion, and I could not help believing that $\mathrm{M}^{\mathrm{rs}}$ Newton and her friends entertained some doubts of the integrity of my intentions ${ }^{\prime} .{ }^{59}$ Nevertheless, Cottle corresponded with Longman and Rees, who replied on 11 January 1804 with an account of the sale of Chatterton's Works: 97 remained of the 350 sold in her aid. She had already been advanced $£ 30$, and was owed another $£ 154-15$ s from sales. ${ }^{60}$ Cottle took the draft for $£ 154-15$ s to Mrs Newton, who was living in Cathay on Redcliffe Hill. She confined to bed when he visited, but received him and he presented the money.
Upon receiving the draft for the for the money, she seemed overwhelmed with joy, and said that she should immediately put the money in the Stocks.... She then held the Draft 「for 154-15ך in her hands, and, in a sort of ecstasy, said to her Daughter 'Well, Mary, I have often had valuable papers in my hands, but I never had such a valuable paper as this before.' I then told her that the object of this money was to render her last days comfortable, and that I hoped she would take every thing that was nourishing, and have a Nurse and proper medical advise (for she appeared in a very weak state) this she promised me she would do, and began to overwhelm me with gratitude. I told her that we were only the instruments, and that she must return thanks to a higher Power. ${ }^{61}$

A grand Cottleism - and indeed a fine gesture (Cottle did not omit to transcribe the accounts of this episode for Southey). Despite its shortcomings, the Southey-Cottle edition succeeded marvellously in its primary aim: to bestow charity on Chatterton's kin by erecting a literary monument to the poet. But it has to be said that for some he would always be a poetaster and nobody. When William Smith, a childhood friend of Chatterton's who lived to the ripe old age of 89, was shown the Southey and Cottle Works shortly before he died on 8 January 1836, he merely shook his head and exclaimed,

'He, Sir! What Tom Chatterton write Rowley's poems? No, Sir, he was incapable of so doing! He no more wrote them than I did! $!^{\prime 62}$

Notes

Transcriptions are diplomatic: to give a taste of Haslewood's self-consciously archaic penmanship, superscript letters are retained, and the 'tilde' contraction is shown by underlining; $<>$ indicate deletions, \lceil\rceil indicate interlineation above line. 
I would like to thank Lynda Pratt for reading and commenting upon this essay.

1. New Letters of Robert Southey, ed. Kenneth Curry (2 vols, New York and London, 1965), i. 302.

2. Nathaniel Biggs was Cottle's master printer, and so the work is under the imprimatur of Biggs and Cottle.

3. Accounts of Southey's spat with Croft are given by Brian Goldberg, 'Romantic Professionalism in 1800: Robert Southey, Herbert Croft, and the Letters of Thomas Chatterton', ELH, 63 (1996), 681-706; and Nick Groom, 'Love and Madness: Southey Editing Chatterton' in Lynda Pratt (ed.), Robert Southey and the Contexts of English Romanticism (Aldershot, 2005), 41-64: the current essay is a companion piece to this latter work. John Brewer has also reconsidered the case that inspired Croft in Sentimental Murder: Love and Madness in the Eighteenth Century (New York, 2004). See also Basil Cottle, Joseph Cottle and the Romantics: The Life of a Bristol Printer (Bristol, 2008), ch. 8.

4. The Complete Works of Thomas Chatterton, ed. Donald S. Taylor and Benjamin B. Hoover (2 vols continuously paginated, Oxford, 1971), i. xxxiii.

5. George Gregory, The Life of Thomas Chatterton, with Criticisms on his Genius and Writings, and a Concise View of the Controversy concerning Rowley's Poems (London, 1789); Thomas Chatterton, Miscellanies in Verse and Prose, ed. John Broughton (London, 1778); Thomas Chatterton, Poems, Supposed to have been Written at Bristol in the Fifteenth Century, by Thomas Rowley, Priest, Ecc., ed. Jeremiah Milles (London, 1782); Barrett, William, The History and Antiquities of the City of Bristol; compiled from Original Records and Authentic Manuscripts, in Public Offices or Private Hands (Bristol, 1789). The British Library has the copy of William Barrett's History and Antiquities of the City of Bristol (Bristol, 1789) used and annotated by Southey and Cottle in the course of their edition (BL C.60.m.2).

6. Edward Gardner, Miscellanies, in Prose and Verse (2 vols, Bristol, 1798).

7. Thomas Chatterton, Poems, Supposed to have been Written at Bristol, by Thomas Rowley, and Others, in the Fifteenth Century, ed. Thomas
Tyrwhitt (London, 1777); Jacob Bryant, Observations upon the Poems of Thomas Rowley: in which the Authenticity of those Poems is Ascertained (London, 1781).

8. Works, ii. 16

9. Works, iii. 495 .

10. Bristol Reference Library [hereafter BRL], B20957v.

11. BRL, B20956r.

12. Catcott wrote rather witlessly to Robert Glynn on 19 March 1799 with regard to Southey, 'whose poetical abilities are superior to the late unfortunate Thos. Chatterton' (quoted by Meyerstein, 488n). Regarding Eagles, see a letter by Richard Smith on the absence of 'The Merrie Tricks of Lamyngetowne' from Southey and Cottle, despite their having applied to Thomas Eagles (or found it in Milles, 183-6, for that matter); Richard Smith received it from John Eagles (see The Poetical Works of Thomas Chatterton, ed. Walter W. Skeat (2 vols, London, 1872), ii. 318). Halsewood's publications include an edition of Ancient Critical Essays upon English Poets and Poësy (2 vols, Triphook, 1811-15), and he also wrote Some Account of the Life and Publications of the late Joseph Ritson, Esq (London, 1824), about whom see The Life and Correspondence of Robert Southey, ed. Charles Cuthbert Southey (6 vols, London, Brown, Green, and Longman, 1849-50), ii. 203.

13. BRL, B20855v

14. Haslewood had compared his collection with that of Edmond Malone's volume of 'Chattertoniana' (Boston Public Library, 1873.XG.3843.5) which while very incomplete in its magazine clippings, contains some George Steevens contributions to the SJC and other papers that Haslewood was unable to trace. For Steevens's contributions, see Arthur Sherbo, The Achievement of George Steevens (New York, 1990), 169-98.

15. It is worth noting that Dyer, himself as former bluecoat of Christ's Hospital, had sent money to the impoverished Coleridge in 1796, and may have also helped Coleridge to get ten guineas from the Royal Literary Fund. Coleridge was, of course, pursued by the fear of poverty, and this is how Paul Magnuson interprets his 'Monody on the Death of Chatterton': as a predominantly financial plea (Paul Magnuson, 'Coleridge's Discursive "Monody on the Death of Chatterton"', Romanticism on the Net, 17 (Feb 2000). For a 
portrait of Dyer, see Charles Lamb's essay,

'Oxford in the Vacation'.

16. All the following letters are transcribed from Haslewood's collection in the British Library, C.39.h.20 [unfoliated].

17. On the question of 'Asaphides', Haslewood wrote on Friday 12 August that he would visit Southey with a selection of texts: 'I propose putting them in my pocket \& calling on you either Sat ${ }^{\mathrm{y}}$ or Monday afternoon \& will then produce to you sufficient proof that $\mathrm{C}$. did not write under the signature of Asaphides'. He must have spoken with Cottle there also, who wrote next on 20 August, 'Since JC had the pleasure of seeing $\mathrm{M}^{\mathrm{r}} \mathrm{H}$, he has, in opposition to $\mathrm{M}^{\mathrm{r}} \mathrm{H}^{\prime}$ s conjecture, received demonstrative evidence that the pieces in the Town \& Country, with the signature of "Asaphides" were really written by Chatterton.' Chatterton did explicitly admit to the signature (letter to Stephens, 20 July 1769, Taylor, i. 338), but it was also a name used by John Lockstone, a linen draper, and probably other writers of the Spouting Club when they wrote in the Augustan style as well. Taylor admits three Asaphidean pieces to the canon.

18. This assumption led to the erroneous attribution and publication of 'Cutholf'.

19. Life and Correspondence of Southey, i. 319; for a new transcription of this letter, see Lynda Pratt, 'Interaction, Reorientation, and Discontent in the Coleridge-Southey Circle, 1797: Two New Letters by Robert Southey', Notes \& Queries (Sept., 2000), 314-21, 318. See n.3 above on the Croft affair.

20. Haslewood's list is very comprehensively transcribed, and very briefly annotated. It is odd however, that he attributes Edward Rushton's Neglected Genius to 'William Bagshaw Steevens' - particularly in light of Cottle's knowledge of the cancelled note to Coleridge's 'Monody'. See John Goodridge, 'Rowley's Ghost: A Checklist of Creative Works Inspired by Thomas Chatterton's Life and Writings', in Thomas Chatterton and Romantic Culture ed. Nick Groom (London, 1999), 262-92: item 115. William Bagshaw Stevens [sic] wrote about Chatterton in his poem 'Retirement' - for which he was praised by Anna Seward. The pursuit of collecting Chattertonian pamphlets and cuttings is apparent in a letter attributed to George Steevens, but more likely by Richard Farmer, in the SJC
(4 April 1782), in which 'R.F.' presents a preliminary checklist.

21. See Meyerstein, 355n.-6n. 'The Exhibition' was first printed in John Ingram, The True Chatterton: A New Study from Original Documents (London, 1910), Appendix B: 295-304 (nevertheless, this is still bowdlerized: see Taylor, Works, ii. 1079).

22. Taylor, Works, i. 557.

23. BRL, B20957r.

24. New Letters of Southey, i. 273. See also Southey to Grosvenor Bedford (30 March 1802): 'I am busy at the Museum, copying unpublished poems of Chatterton, the which forthwith go to press' (Life and Correspondence, ii. 183).

25. Joseph Cottle, Malvern Hills, with Minor Poems, and Essays (4th edn, London, 1829), ii. 425n.

26. See also Cottle's Early Recollections (293n) for persistent (and ungrounded) doubts over 'Memoirs of a Sad Dog'. Nearly all of the 'Hunter of Oddities' series was attributed to Chatterton, who had himself claimed only June 1770.

27. Haslewood's graingerized copy of Milles, unfoliated (BL, C.39.h.20); see Taylor, Works, ii. 1068. 'Graingerizing' refers to the habit of collectors of interleaving their books with additional pages mounted with prints or cuttings, and for annotation.

28. Taylor, Works, i. 476.

29. The 'witches' teat', a tell-tale mark bestowed by the devil and the place where devilkin and familiars might suckle, was often in a 'secret place', suggesting a more salacious reading of these lines; see John Gay, 'The Old Woman and her Cats': 'Straws laid across my pace retard, / The horse-shoe's nail'd (each threshold's guard) / The stunted broom the wenches hide, / For fear that I should up and ride; / They stick with pins my bleeding seat, / And bid me show my secret teat' (Fables (London, 1728), XXIII, 90).

30. BRL, B22225r; Works, iii. 524-5. Interestingly, this letter goes on to describe again the discovery of the parchments, and her father's researches into the sextons of St Mary Redcliffe: 'Father affirm ${ }^{\mathrm{d}}$ the family had held that Office to use his own phrase, Time out of Mind'.

31. Works, iii. 524, ii. 66n, iii. 375-6.

32. The De Bergham pedigree and Chatterton's letter to the herald Ralph Bigland had first been published 10 Oct 1787 in GM, and by 1789 the two copybooks were in the possession of Thomas Eagles. Cottle obtained them via Mary Newton. 
Chatterton's letter to Ralph Bigland 'proves him to have been no mean adept in the science of Heraldry' (GM (Nov 1787), 954). The article, signed 'J.D.', also alludes to the De Bergham pedigree.

33. Works, ii. 455. This essay appears in an almost completely rewritten version in Cottle's Malvern Hills (ii. 382-95), incorporating some semi-fictitious exchanges between Chatterton and Henry Burgum, lengthy quotation from the text of the pedigree, and the accounts from Chatterton's pocket book-although it does conclude on the same note.

34. Works, ii. 457.

35. Works, ii. 458.

36. Works, ii. 460.

37. Works, ii. 461-2.

38. Works, ii. 462.

39. William Henry Ireland was presumably in Bristol to negotiate with Biggs and Cottle over his Ballads in Imitation of the Ancient (1801). He also visited Mary Newton on this trip: see The Confessions of William-Henry Ireland (London, 1805), 13. Ireland is an interesting case of another 'early Romantic' who wrote in as bewildering an array of styles as did Chatterton (see Nick Groom, The Forger's Shadow: How Forgery Changed the Course of Literature (London, 2002), 251-2).

40. Also heavily revised for Malvern Hills, ii. 412-32, including some remarks upon Chatterton's plagiarisms from Shakespeare, inspired by George Steevens's series of articles in the SJC (these commenced 22 January 1782).

41. Works, ii. 518. For such arguments, see, for example, a letter signed 'Y.Z' (SJC 21 September 1782), and Poems, by the Rev. W. Tasker, A.B. (London: privately printed, 1779), 48-9nn.

42. Works, ii. 518-19.
43. Inga Bryden 'The Mythical Image: Chatterton, King Arthur, and Heraldry' in Thomas Chatterton and Romantic Culture, 73.

44. This too is rewritten in Malvern Hills: ii. 396-409; Works, iii. 507.

45. Cottle, Malvern Hills, ii. 409.

46. Cottle, Malvern Hills, ii. 411.

47. Bristol Journal, 27 Dec 1828: see BRL, B35.

48. Joseph Cottle, Early Recollections; chiefly relative to the late Samuel Taylor Coleridge, during his long residence in Bristol (2 vols, London, 1837), i. 273-4. See also Joseph Cottle, Reminiscences of Samuel Taylor Coleridge and Robert Southey (London: Houlston and Stoneman, 1847).

49. Cottle, Malvern Hills, ii. 431.

50. Cottle, Malvern Hills, ii. 431.

51. Life and Correspondence of Southey, ii. 298.

52. Edinburgh Review 4 (April 1804), 218. The edition was subsequently translated into French prose in 1839 by Javelin Pagnon, and in 1840 seven Rowley poems were translated into German by Hermann Püttmann.

53. Edinburgh Review 4 (April 1804), 218.

54. Edinburgh Review 4 (April 1804), 230.

55. Henry Crabb Robinson on Books and their Writers, ed. Edith J. Morley (2 vols, London, 1938), ii. 610.

56. Crabb Robinson, ii. 611.

57. John Dix, The Life of Thomas Chatterton (London, 1837).

58. See Groom, 'Love and Madness', passim.

59. BRL, B20877 (1) 1v.

60. BRL, B21041 (1)r. In the accompanying letter, the publishers expected that as many as 30-40 of the subscriptions would be returned due to subscribers dying.

61. BRL, B20877 (1) 1v.

62. Quoted by Ingram, 118. 